\begin{tabular}{cc|c}
\hline Tar. Bil. Der. & Tarım Bilimleri Dergisi & Journal of Agricultural Sciences \\
& $\begin{array}{c}\text { Dergi web sayfası: } \\
\text { www.agri.ankara.edu.tr/dergi }\end{array}$ & Journal homepage: \\
& www.agri.ankara.edu.tr/journal
\end{tabular}

\title{
Değişik Yöntemlerle Islah Edilen Meralarda Bazı Toprak Kalite Özelliklerinin Değişimi
}

\author{
Cafer TÜRKMEN ${ }^{a}$, Nuray Mücellâ MÜFTÜOĞLU', Yasemin KAVDIR ${ }^{a}$ \\ ${ }^{a}$ Çanakkale Onsekiz Mart Üniversitesi, Ziraat Fakültesi, Toprak Bilimi ve Bitki Besleme Bölümü, Terzioğlu Yerleşkesi, 17100, Çanakkale, TÜRKiYE
}

\section{ESER BILGISII}

Araştırma Makalesi — Bitkisel Üretim ～https://doi.org/10.1501/Tarimbil_0000001250

Sorumlu Yazar: Cafer TÜRKMEN, E-posta: turkmen@comu.edu.tr, Tel: +90 (0 286) 21800 18/1316

Geliş Tarihi: 02 Ağustos 2013, Düzeltmelerin Gelişi: 25 Eylül 2013, Kabul: 25 Eylül 2013

\begin{abstract}
ÖZET
$\mathrm{Bu}$ çalışma; farklı yöntemler uygulanarak ıslah edilen mera alanında ıslah uygulamalarının bazı toprak kalite özelliklerine etkisini belirlemek amacıyla yapılmıştır. Bu amaçla, 2008 ve 2009 yılları Mayıs ayının ikinci haftasında 5 farklı 1slah yöntemi uygulanan mera alanından ve herbir ıslah uygulama alanının sekiz farklı yerinden 0-15 ve 15-30 $\mathrm{cm}$ derinliklerinden toprak örnekleri alınmıştır. Alınan toprak örneklerinde; toprak reaksiyonu, toprak tuzluluğu, kireç içeriği, toplam karbon, toplam azot, agregat stabilitesi, kuru hacim ağırlığı, tane yoğunluğu, katalaz enzim aktivitesi, üreaz enzim aktivitesi ve mezofil aerobik mikroorganizma sayıları tekrarlanan ölçümlerle incelenmiştir. Elde edilen verilerin istatistik analizlerine göre ıslah uygulamalarının; toprak reaksiyonu, toprak tuzluluğu, kireç yüzdesi, toplam azot, agregat stabilitesi, katalaz enzim aktivitesi ve mezofil mikroorganizma sayıları özelliklerine etkisinin önemli düzeyde $(\mathrm{P}<0.01)$ olduğu bulunmuştur. Ayrıca uygulamaların, toplam karbon miktarı ile üreaz enzim aktivitesine etkisinin önemli $(\mathrm{P}<0.05)$ olduğu görülmüştür. Toprak derinliğinin tuzluluk, toplam karbon, katalaz ve üreaz enzim aktiviteleri özelliklerine $\mathrm{P}<0.01$ düzeyinde önemli etki yaptığ toplam azot, agregat stabilitesi, kuru hacim ağırlı̆̆1, tane yoğunluğu ve mezofil mikroorganizma sayısı özelliklerine $\mathrm{P}<0.05$ düzeyinde etkili olduğu görülmüştür. İncelenen özelliklerin hiçbirinde uygulama ve derinliğin birlikte etkisinin (interaksiyon etkisi) önemsenecek düzeylerde olmadığı bulunmuştur.

Anahtar Kelimeler: Mera; Mera 1slahı; Toprak; Toprak kalitesi
\end{abstract}

\section{Change of Some Soil Quality Characteristics under Different Pasture Reclamation Methods of Rangelands}

\section{ARTICLE INFO}

Research Article - Crop Production

Corresponding Author: Cafer TÜRKMEN, E-mail: turkmen@comu.edu.tr, Tel: +90 (0 286) 21800 18/1316

Received: 02 August 2013, Received in Revised Form: 25 September 2013, Accepted: 25 September 2013

\section{ABSTRACT}

The present study was conducted to investigate the effects of different pasture reclamation methods on soil characteristics. For this purpose, soil samples were taken from $0-15$ and 15-30 $\mathrm{cm}$ depths of the pasture lands subjected to 5 different 
reclamation processes from 8 different locations of each process during the second week of May of 2008 and 2009. Soil reaction, soil salinity, lime content, total carbon, total nitrogen, aggregate stability, bulk density, particle density, catalase and urease enzyme activities and mesophyllic aerobic microorganism count tests were carried out on soil samples for two years. Effects of reclamation processes on soil reaction, soil salinity, lime content, total nitrogen, aggregate stability, catalase enzyme activity and mesophyllic microorganism counts found to be significant at $\mathrm{P}<0.01$ level. Effects of treatments on total carbon and urease enzyme activity were found to be significant at $\mathrm{P}<0.05$ level. Effects of soil depth on soil salinity, total carbon, catalase and urease enzyme activities were found to be significant at $\mathrm{P}<0.01$ level; soil reaction, total nitrogen, aggregate stability, bulk density, partical density and mesophyllic microorganism counts were found to be significant at $\mathrm{P}<0.05$ level. Interactions of treatments and depth were not significant at any level.

Keywords: Pasture; Pasture reclamation; Soil; Soil quality

\section{Giriş}

Dünyada karaların yaklaşık \% 25'ini meralar kaplamaktadır (Ojima et al 1993). Türkiye'de bu oran \% 18.8'dir. Çanakkale ise 22153.6 ha (\% 2.22) çayır ve mera alanı ile oldukça az meraya sahip illerdendir (ÇOB 2007). Dünya gıda üretiminin \% 16'sı nın meralardan sağlandığı belirtilmektedir (Holechek et al 2004). Meraların dünya hayvansal üretimindeki kaba yem ihtiyacının yaklaşık \% 70'ini temin ettiği tahmin edilmektedir (Lund 2007).

Meralarda uygun olmayan otlatmalar sonucunda, özellikle Akdeniz ikliminin hüküm sürdüğü alanlarda, tek yıllık bitki türleri ile karaçalı (Paliurus spina-cristi), aptesbozan (Sarcopoterium spinosum) gibi dikenli çalılar ve dikensi yapraklı ardıç (Juniperus oxycedrus) vejetasyonunda önemli artışlar gözlendiği birçok araştırmacı tarafından belirtilmektedir (Montalvo et al 1993; Seligman 1996; Lavorel et al 1999; Sternberg et al 2000; Gökkuş et al 2001; Özaslan Parlak 2011). Keçi otlatılmayan bölgelerde ise yoğun olarak karaçalı bulunmaktadır. Aşırı otlatmanın mera bitkileri türlerine olan baskısı (Şekercioğlu et al 2011; Firıncioğlu et al 2007; Heady 1973; Stoddart et al 1975) yanında topraklara da baskısı olmaktadır (Özaslan Parlak et al 2011a; Oğuz, 2012; Mikhailova et al 2000; Langdale et al 1992; Nael et al 2004).

Türkiye'de son yıllarda çıkarılan 4342 sayılı mera kanunu ve ilgili yönetmelikler mera konusunun önemine işaret etmektedir (RG 1998). Bu kapsamda, Gıda Tarım ve Hayvancılık Bakanlığı bünyesinde mera ıslah çalışmaları tüm Türkiye çapında başlatılmıştır. Meralarda bitki örtüsü ıslahında çeşitli yöntemler kullanılmaktadır. Çalıların yok edilmesinde mekanik ve kimyasal mücadele önemli bir yere sahiptir (Gökkuş et al 2001). Mera 1slah çalışmalarının sonucunda kısmen gözle görülür başarılar elde edilmiş, ancak sonuçlar birçok mera ıslah alanında gözleme dayalı olarak kalmış ve bilimsel olarak ele alınan araştırma sayısı (Mülayim 1980; Fidan 2002; Kökten 2005; Kadığlu 2007; Çetiner 2009) sınırlı olmuştur. Bu konuda 8500'den fazla yabancı yayına rastlanmış ancak, ingilizce anahtar kelimelerle; tarama islah yöntemleri, toprak kalitesi, şeklinde sınırlandırıldığında bazı münferit toprak özelliklerin incelendiği birkaç çalışma dişında (Öztaş et al 2003; Nael et al 2004; Liu et al 2010; Zavala et al 2011; Lal 2011) genel anlamda doğrudan 1slah metotları ile toprak kalite parametrelerinin ilişkisini sorgulayan çalışmalara rastlanmamıştır.

$\mathrm{Bu}$ araştırmada; Çanakkale ili meralarının \% 40'ına ve büyükbaş hayvanların \% 34'üne sahip olan Biga ilçesinde (Çetiner 2009), Çanakkale İl Gıda Tarım ve Hayvancılık Müdürlüğü tarafından değişik yöntemlerle islah edilmiş bir mera olan Hacıpehlivan köyü merasında yapılan islah çalışmalarının bazı toprak kalite özelliklerine etkilerinin bilimsel olarak değerlendirilmesi kurgulanmıştır. Bu amaçla; iki farklı derinlikten ve iki yıllık dönemden elde edilen verilerle mera 1slah ve yönetim uygulamalarının toprak özelliklerine ve toprak kalitesine olumlu ya da olumsuz etkilerin boyutu tespit edilmeye çalışılmıştır. 


\section{Materyal ve Yöntem}

\subsection{Materyal}

Deneme materyali olarak kullanılan mera alanı Biga (Çanakkale-Türkiye) ilçesi doğusunda, ilçeye $17 \mathrm{~km}$ ve Çanakkale'ye $120 \mathrm{~km}$ uzaklıkta bulunan Hacipehlivan köyünün 113.2 hektarlık mera alanıdır. Mera alanı kuzey-güney doğrultusunda yaklaşı $2 \mathrm{~km}$ uzunluk ve doğu-batı doğrultusunda $0.5 \mathrm{~km}$ genişliktedir. Mera alanı köy yerleşim yerine bitişik ve köyün kuzeyinde doğu-batı hattı boyunca uzanmaktadır. Sinırları; kuzeyden $\left(40^{\circ} 15^{\prime}\right.$ $\left.09^{\prime \prime} \mathrm{K} / 27^{\circ} 24^{\prime} 24^{\prime \prime} \mathrm{D}\right)$ - ( $40^{\circ} 15^{\prime} 16^{\prime \prime} \mathrm{K} / 27^{\circ} 24^{\prime}$ $\left.58^{\prime \prime} \mathrm{D}\right)$ ve güneyden $\left(40^{\circ} 14^{\prime} 20^{\prime \prime} \mathrm{K} / 27^{\circ} 25^{\prime} 27^{\prime \prime}\right.$ D) - ( $\left.40^{\circ} 14^{\prime} 25^{\prime \prime} \mathrm{K} / 27^{\circ} 25^{\prime} 36^{\prime \prime} \mathrm{D}\right)$ koordinatları ile çevrilmektedir (Şekil 1). Ölçümler "Magellan 310" el tipi coğrafi konum belirleme Global Positioning System (GPS) cihazı ile yapılmıştır. Merada 400 büyükbaş, 55 keçi ve 40 koyun olmak üzere 95 küçükbaş hayvanın otlatıldığg belirtilmiştir (Çetiner 2009).

Mera alanındaki çalıların (Paliurus spinachristi Mill.) farklı yöntemlerle uzaklaştırılarak bertaraf edilmesi ve islah uygulamalarına göre mera alanı beş guruba ayrılmıştır. Bunlar: hiçbir çalı mücadelesi yapılmayan (1slah uygulanmayan doğal olarak bırakılan çalılık mera alanı), kontrol merası (A), 1989 yılında sürülüp mera bitkileri ekimi yapılan alan (B), Glyphosate içeren ot öldürücülerle (Roundup) münferiden ilaçlanarak öldürülen çalıların uzaklaştırılması sonrası mera bitkileri ekimi yapılan alan (C), 2004 yılında Dozer + Ripper aleti ile çalılar kökünden sökülerek (yaklaşık 25-30 $\mathrm{cm}$ ) uzaklaştırılmasından sonra mera bitkileri ekimi yapilan alan (D) ve uzun yıllar (15 y1l) tarla olarak kullanıldıktan sonra yeniden mera bitkisi ekimi yapılan alan (E) gruplarıdır.

Mera alanlarına islah amaciyla yapılan ekimler, dörtlü karışım olarak \% 40 baklagil, $\% 60$ buğdaygil yem bitkileri şeklinde yapılmıştır. Ekimden sonra bir yıl süreyle merada otlatma yapılmayarak ekilen türlerin kuvvetli kök oluşturmaları temin edilmiştir. Kontrol dışındaki alanlarda ekim sırasında gübre kullanılmamış, gübreleme 2005 ve 2007 yıllarında $3 \mathrm{~kg} \mathrm{da}^{-1}$ azot (N), $3 \mathrm{~kg} \mathrm{da}^{-1}$ fosfor (P) ve $3 \mathrm{~kg} \mathrm{da}^{-1}$ potasyum (K) olacak şekilde 15-15-15 kompoze gübresi ile yapılmıştır. Takip eden yıllarda gübreleme yapılmamıştır.

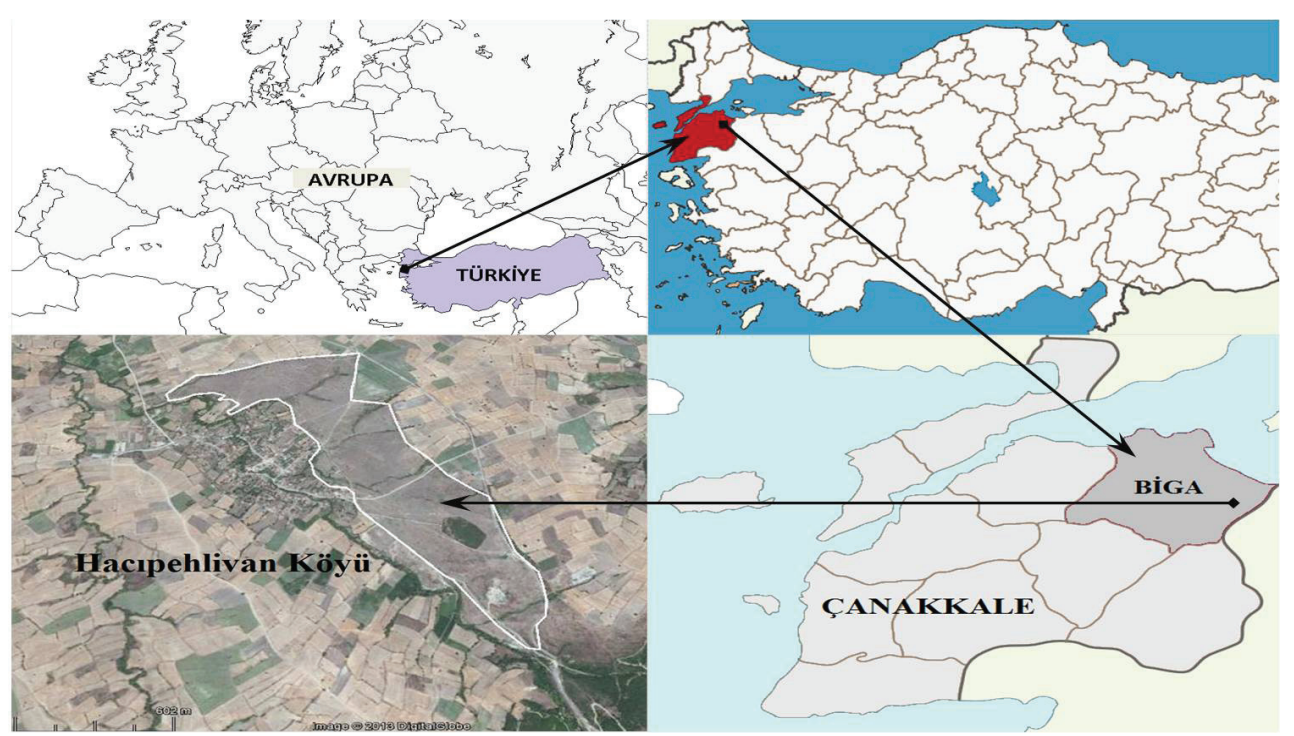

Şekil 1- Araştırma sahası

Figure 1-Reserach site 


\subsection{Deneme alanının iklim özellikleri}

Marmara geçit iklimi özellikleri gösteren mera alanının uzun yıllar iklim verileri ile deneme zamanına ait iklim verileri Çizelge 1'de verilmiştir (MGM 2013). Çalışma alanının iklim verilerine bakıldığında (Çizelge 1) çalışmanın yürütüldüğü her iki yılda da ortalama sıcaklıklar uzun y1llar ortalamasının üzerinde seyretmiştir. Yağışlar ise 2008 yılında oldukça düşükken 2009 yılı yağışları uzun yıllar ortalamasından fazla olmuştur.

\subsection{Toprak özelliklerinin incelenmesi ve verilerin elde edilmesi}

Merada her bir 1slah uygulama alanı için, o alanın sekizer yerinden ve ikişer derinlikten $(0-15,15-30$ $\mathrm{cm})$ toprak örnekleri alınmıştır. GPS yardımıyla yerleri saptanan noktalardan ertesi yıl da aynı yer ve derinliklerden örnekleme yapılmıştır. Alınan örnekler polietilen torbalarla laboratuvara nakledilmiş ve hava kuru toprak haline getirilerek 2 mm'lik elekten elenmiş (Jackson 1958) ve Çizelge 2'deki yöntemlere göre toprak analizleri yapılmıştır. Mikrobiyal amaçlı örnekleme ise Winogradsky (1952) metoduna göre; her noktadan el burgusuyla alınan en az beş örneğin homojenize edilerek havadar koşullarda arazi tip soğutucularla muhafaza altına alınarak, örneklerin laboratuvara nakledilmesi şeklinde yapılmıştır. Örneklemede değişik derinlik ve uygulamalardan alınan farklı örnekler arasında kullanılan ekipmanlar \% 96'l1k etil alkol ile dezenfekte edilmiştir. Bozulmamış toprak örnekleri ise $100 \mathrm{~cm}^{3}$ 'ük çakma silindirleri kullanılarak (Blake \& Hartge 1986) her 1slah uygulama alanının sekizer noktasından ve ikişer derinlikden alınmıştır.

Çizelge 1- Deneme yeri iklim verileri (Biga-Çanakkale)

Table 1-Climate data for research site (Biga-Çanakkale)

\begin{tabular}{|c|c|c|c|c|c|c|}
\hline \multirow{2}{*}{ Aylar } & \multicolumn{6}{|c|}{ Yillar } \\
\hline & 2008 & 2009 & $1970-2013^{*}$ & 2008 & 2009 & $1970-2013^{*}$ \\
\hline & \multicolumn{3}{|c|}{ Stcakllk $\left({ }^{\circ} \mathrm{C}\right)$} & \multicolumn{3}{|c|}{ Yağıș $(m m)$} \\
\hline Ocak & 4.5 & 7.8 & 5.2 & 22.0 & 80.2 & 88.8 \\
\hline Şubat & 5.5 & 7.2 & 5.5 & 9.4 & 110.9 & 75.1 \\
\hline Mart & 11.3 & 8.8 & 7.8 & 34.2 & 80.1 & 62.8 \\
\hline Nisan & 13.7 & 12.2 & 12.1 & 48.0 & 40.3 & 55.4 \\
\hline May1s & 17.7 & 18.4 & 16.7 & 0.2 & 17.9 & 38.6 \\
\hline Haziran & 23.4 & 22.7 & 21.5 & 6.3 & 16.1 & 25.1 \\
\hline Temmuz & 25.8 & 26.4 & 23.6 & 0.6 & 1.2 & 11.5 \\
\hline Ağustos & 26.1 & 25.3 & 23.3 & 34.1 & 0.0 & 14.6 \\
\hline Eylül & 20.5 & 20.6 & 19.3 & 32.2 & 39.8 & 28.4 \\
\hline Ekim & 16.4 & 17.6 & 14.9 & 55.5 & 63.6 & 55.8 \\
\hline Kasım & 13.1 & 12.5 & 10.0 & 43.2 & 58.8 & 96.5 \\
\hline Aralık & 8.6 & 11.0 & 7.0 & 58.2 & 176.7 & 104.4 \\
\hline Ortalama & 15.6 & 15.9 & 13.9 & 343.9 & 685.6 & 657.0 \\
\hline
\end{tabular}

", Uzun y1llar ortalamas1 


\section{Çizelge 2- Deneme topraklarının analizleri ve kullanılan metotlar}

Table 2-Analyses and methods for experimental soils

\begin{tabular}{|c|c|c|}
\hline Analizler & Açıklama & Metotlar \\
\hline Toprak reaksiyonu $(\mathrm{pH})$ & Toprak-Su karışımında $(1: 2.5)$ & Jackson (1958) \\
\hline Toprak tuzluluğu & Toprak-Su karışımında $(1: 2.5)$ & Richards (1954) \\
\hline Toplam $\mathrm{C}$ ve $\mathrm{N}$ & LECO C-N elementel analiz cihazı ile & Kirsten (1983) \\
\hline Kireç & Scheibler kalsimetresinde volümetrik olarak & Allison \& Moodie (1965) \\
\hline Kum-Silt-Kil & Organik maddesi ve kireci giderilen örneklerde & Bouyoucos (1951) \\
\hline Bitkiye yarayışlı $\mathrm{P}$ & $0.5 \mathrm{M} \mathrm{NaHCO}_{3}(\mathrm{pH}=8.5)$ ile çözeltiye alınan P'dan & Olsen et al (1954) \\
\hline Agregat stabilitesi & Islak eleme metodu ile & Kemper \&Rosenau (1986) \\
\hline Tane yoğunluğu & Fırın kuru ağırlığın, toprak katı kısmınınhacmine bölümü ile & Blake \& Hartge (1986) \\
\hline Kuru hacim ağırlı̆̆ 1 & Fırın kuru ağırlığın toplam hacme bölümü ile & Blake \& Hartge (1986) \\
\hline Üreaz enzim aktivitesi & $\begin{array}{l}\text { Hava kuru } 2 \mathrm{~mm} \text { 'lik elekten geçirilmiş topraklarda, ürenin } \\
3 \text { saat } 37^{\circ} \mathrm{C} \text { derecede inkübasyonu sonrası }\end{array}$ & Hoffmann \&Teicher (1961) \\
\hline Katalaz enzim aktivitesi & $\begin{array}{l}\text { Hava kuru } 2 \text { mm'lik elekten geçirilmiş topraklarda, } \mathrm{H}_{2} \mathrm{O}_{2}{ }^{\prime} \mathrm{i} \\
\text { parçalayan enzimin çıkardığ } \mathrm{O}_{2} \text { gazından }\end{array}$ & Beck (1971) \\
\hline Mikroorganizma sayıs1 & Winogradsky (1952)'e göre taze örneklerde & Wollum (1982) \\
\hline
\end{tabular}

\subsection{Verilerin istatistik analizi}

Elde edilen verilere, mera alanlarının ve derinliklerin karşılaştırılması amacıyla tek yönlü varyans analizi tekniği uygulanmıştır. İncelenen özellikler arasındaki farklılık " $F$ " testi ile belirlenmiştir. Ortalamalar arasındaki fark1 belirlemek için En Küçük Önemli Fark (Least Significant Difference; $L S D$ ) testi kullanılmıştır. Söz konusu istatistik analizlerinin yapılmasında SAS istatistik paket programından yararlanılmıştır (SAS 2000).

\section{Bulgular ve Tartışma}

\subsection{Toprak kimyasal özellikleri}

Toprak özelliklerinin varyans analiz değerlerine göre toprağın pH's1 ve tuzluluğu, hem islah uygulama tipine hem de toprak derinliğine bağlı olarak değişirken kireç miktarı sadece ıslah uygulama tipine göre değişmiştir. Kirecin toprak derinliğine göre değişimi (Çizelge 3) önemsiz olmuştur.
Çizelge 3- Toprak kimyasal özelliklerinin ıslah tipi ve toprak derinliğine göre değişimi

Table 3-Variation of soil chemical characteristics with reclamation process and soil depth

\begin{tabular}{cccc}
\hline $\begin{array}{c}\text { Uygulama tipi/ } \\
\text { Toprak derinliği }\end{array}$ & $\begin{array}{c}\text { Toprak } \\
\text { reaksiyonu } \\
(p H)\end{array}$ & $\begin{array}{c}\text { Tuz } \\
(\mu m h o s \\
\left.\mathrm{cm}^{-1}\right)\end{array}$ & $\begin{array}{c}\text { Kireç } \\
(\%)\end{array}$ \\
\hline $\mathrm{A}^{1}$ & $7.70 \mathrm{a}^{\#}$ & $204.31 \mathrm{~b}$ & $3.82 \mathrm{a}$ \\
$\mathrm{B}$ & $7.32 \mathrm{~b}$ & $155.77 \mathrm{c}$ & $2.08 \mathrm{~b}$ \\
$\mathrm{C}$ & $6.61 \mathrm{c}$ & $162.54 \mathrm{c}$ & $0.66 \mathrm{c}$ \\
$\mathrm{D}$ & $7.53 \mathrm{a}$ & $301.24 \mathrm{a}$ & $2.89 \mathrm{ba}$ \\
$\mathrm{E}$ & $7.50 \mathrm{ba}$ & $293.70 \mathrm{a}$ & $2.24 \mathrm{~b}$ \\
$\mathrm{~F} \mathrm{değeri}_{\text {LSD }}$ & $31.86^{* * * *}$ & $22.99^{* * *}$ & $9.06^{* * *}$ \\
\hline $\mathrm{I}^{2}$ & 0.212 & 40.84 & 1.08 \\
$\mathrm{II}^{\text {F değeri }}$ & $7.25 \mathrm{~b}$ & $249.13 \mathrm{a}$ & 2.64 \\
$\mathrm{LSD}_{0.05}$ & $5.41 \mathrm{a}$ & $197.90 \mathrm{~b}$ & 2.04 \\
\hline
\end{tabular}

$\overline{{ }^{\alpha} \text {, Uygulamalara göre elde edilen ortalamalar için } n=32 \text {, derinliğe }}$ göre elde edilen ortalamalar için $n=80$ ' dir. ${ }^{1} \mathrm{~A}$, Kontrol; B, 15 yıl önce 1slah edilen; C, Ot öldürücü ile çalıları öldürülen; D, Dozerle çalıları sökülen; E, Uzun yıllar tarım yapılmaktayken yeniden 1 slah edilen mera alanlarını göstermektedir. ${ }^{2}$ I, 0-15 $\mathrm{cm}$ derinlikten alınan örnekleri; II, 15-30 cm derinlikten alınan örnekleri göstermektedir. \#, Farklı harfler aynı sütundaki farklı grupları simgelemektedir. ${ }^{* * *}, \mathrm{P}<0.001,{ }^{*}, \mathrm{P}<0.05$ önem

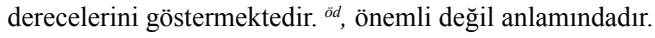


Kontrol merasında $\mathrm{pH}$ ve kireç içerikleri diğer alanlara göre yüksek bulunmuştur. $\mathrm{C}$ uygulaması yapılan mera alanında en düşük kireç ve $\mathrm{pH}$ değerleri görülmüştür. $\mathrm{Bu}$ alandaki düşük $\mathrm{pH}$ seviyelerinin uygulanan ilaçlamaya bağımlı olmayacağı jeolojik yapıdan kaynaklanabileceği düşünülmektedir. Çünkü ilaçlama münferit çalı ilaçlaması şeklinde yapılmış ve biyolojik ölümü gerçekleşen çalılar sökülerek ortamdan uzaklaştırılmışlardır. Toprak pH'sının kireçle doğrudan ilişkili olduğu (Richard 1954) uzun yıllardır bilinen bir durumdur. D ve E mera alanlarının tuz seviyeleri diğer gruplardan yüksek olmuş, en düşük tuz değerleri $\mathrm{B}$ ve $\mathrm{C}$ alanlarında ölçülmüştür. İncelenen topraklarda $\mathrm{pH}$ ve tuz özelliklerinde üst toprakta $(0-15 \mathrm{~cm})$ yüksek değerler görülmüşken, topraktaki kireç değişimi derinliklere göre önemsiz olmuştur (Çizelge 3 ).

Çetiner (2009), aynı bölgede uzun yıllar tarla olarak kullanıldıktan sonra sslah edilerek yeniden mera haline getirilen bir alanda yaptığı çalışmada, incelediği özellikler içinden toprak reaksiyonu, EC ve değişebilir Mg'un önemli oranda değişmediğini belirtmiştir. Kadığlu (2007) ise üç topoğrafik pozisyonda yaptığı çalışmada tepe konumundan etek konumuna doğru, araştırmaya konu olan toprak kalite parametrelerinin değerlerinin arttığını ve örneklenen A horizonunda B horizonuna göre bu parametrelerin daha yüksek değerlere ulaştığını belirtmiştir. Bu çalışma, horizon bazında örnekleme yapılan ve kalite özelliklerine değinen az sayıdaki çalışmalardandır. Farklı ekolojik koşullar olsa da, yaptığımız çalışmada üst toprakların özellikleri benzer sonuçlar göstermiştir.

\subsection{Toprak biyolojik özellikleri}

Araştırmada toprak biyolojik kalite parametreleri olarak mikroorganizma sayıları, üreaz ve katalaz enzimleri ile toplam azot ve karbon içerikleri (Nortcliff 2002; Nannipieri 1994; Dick 1994) ele alınmıştır. İncelenen bu özellikler 1slah uygulamalarına ve derinliklere göre farklar göstermiş, farklar istatistikî olarak önemli olmuştur (Çizelge 4).

\section{Çizelge 4- Toprak biyolojik özelliklerinin ıslah tipi ve toprak derinliğine göre değişimi}

Table 4-Variation of soil biological characteristics with reclamation process and soil depth

\begin{tabular}{|c|c|c|c|c|c|}
\hline $\begin{array}{c}\text { Uygulama tipi/ } \\
{\text { Toprak derinliğ }{ }^{\alpha}}^{\alpha}\end{array}$ & $\begin{array}{c}\text { Mikroorganizma } \\
\text { saylst } \\
\left(x 10^{6}\right) \\
\end{array}$ & $\begin{array}{l}\text { Katalaz } \\
\text { (mg } \mathrm{O}_{2} 5 \mathrm{~g}^{-1} \\
\text { toprak) }\end{array}$ & 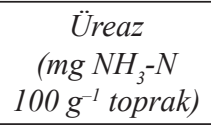 & $\begin{array}{c}\text { Toplam } C \\
(\%)\end{array}$ & $\begin{array}{c}\text { Toplam } N \\
\text { (\%) }\end{array}$ \\
\hline $\mathrm{A}^{1}$ & $6.65 \mathrm{a}^{\#}$ & $7.42 \mathrm{a}$ & $40.24 \mathrm{a}$ & $3.16 \mathrm{ba}$ & $0.213 \mathrm{~b}$ \\
\hline B & $6.17 \mathrm{~b}$ & $6.83 \mathrm{~b}$ & $34.18 \mathrm{ba}$ & $2.78 \mathrm{c}$ & $0.209 \mathrm{~b}$ \\
\hline $\mathrm{C}$ & $6.01 \mathrm{~b}$ & $3.72 \mathrm{c}$ & $31.43 \mathrm{~b}$ & $3.14 \mathrm{bac}$ & $0.300 \mathrm{a}$ \\
\hline D & $6.16 \mathrm{~b}$ & $6.69 \mathrm{ba}$ & $40.07 \mathrm{a}$ & $3.36 \mathrm{a}$ & $0.284 \mathrm{a}$ \\
\hline E & $6.17 \mathrm{~b}$ & $5.72 \mathrm{~b}$ & $38.89 \mathrm{a}$ & $2.95 \mathrm{bc}$ & $0.218 \mathrm{~b}$ \\
\hline $\mathrm{F}$ değeri & $12.89^{* * *}$ & $8.22^{* * *}$ & $2.93^{*}$ & $3.00^{*}$ & $6.06^{* *}$ \\
\hline $\mathrm{LSD}_{0.05}$ & 0.28 & 53.93 & 1.43 & 0.36 & 0.065 \\
\hline $\mathrm{I}^{2}$ & $6.29 \mathrm{a}$ & $6.67 \mathrm{a}$ & $43.42 \mathrm{a}$ & $3.35 \mathrm{a}$ & $0.262 \mathrm{a}$ \\
\hline II & $6.17 \mathrm{~b}$ & $5.48 \mathrm{~b}$ & $30.51 \mathrm{~b}$ & $2.81 \mathrm{~b}$ & $0.228 \mathrm{~b}$ \\
\hline F değeri & $3.97^{*}$ & $6.84^{* *}$ & $39.05^{* * *}$ & $22.13^{* * *}$ & $4.47^{*}$ \\
\hline $\mathrm{LSD}_{0.05}$ & 0.12 & 0.89 & 4.08 & 0.23 & 0.03 \\
\hline
\end{tabular}

${ }^{\alpha}$, Uygulamalara göre elde edilen ortalamalar için $n=32$, derinliğe göre elde edilen ortalamalar için $n=80$ 'dir. ${ }^{1} \mathrm{~A}, \mathrm{Kontrol}$; B, 15 y1l önce ıslah edilen; C, Ot öldürücü ile çalıları öldürülen; D, Dozerle çalıları sökülen; E, Uzun yıllar tarım yapılmaktayken yeniden 1slah edilen mera alanlarını göstermektedir. ${ }^{2}$ I, 0-15 cm derinlikten alınan örnekler; II, $15-30 \mathrm{~cm}$ derinlikten alınan örnekleri göstermektedir. \#, Farklı harfler aynı sütundaki farklı grupları simgelemektedir. ${ }^{* * *}, \mathrm{P}<0.001 ;{ }^{* *}, \mathrm{P}<0.01 ;{ }^{*}, \mathrm{P}<0.05$ önem derecelerini göstermektedir. 
Üreaz enzimi ürenin $\mathrm{CO}_{2}$ ve $\mathrm{NH}_{3}$ 'a hidrolizini katalize eden enzimdir (Dick 1994). Hofmann ve Hoffmann (1966) toprakları üreaz enzimini aktivitelerine göre düşük $(<8)$, normal $(8-16)$ ve yüksek $(>16)$ terimleriyle 3 düzeye ayırmıştır. $\mathrm{Bu}$ kriterlere göre, mera alanlarının tamamının yüksek üreaz seviyesinde olduğu görülmüştür. Üreaz ve mikroorganizma sayılarının $\mathrm{C}$ uygulamasında en az olduğu ve en yüksek değerlerin kontrol uygulamasında olduğu görülmüştür. $\mathrm{Bu}$ durumun $\mathrm{C}$ uygulamasında ot öldürücülerin kullanılmasına bağlanmamalıdır. Üreaz ve mikroorganizma sayılarının düşük pH ile ilişkili olabileceği düşünülebilir (Dick 1994). Çünkü ilaçlama satıh ilaçlaması değil, münferiden çalı yeşilken taç bölgesine yapılmıştır, yani topraktan mümkün olduğu kadar uzak tutulmaya çalışılmıştır. Ayrıca diğer uygulamalarda da $\mathrm{C}$ alanına göre yüksek biyolojik aktiviteler bulunmuştur. Yapılan bu çalışmada, üst toprakların enzim aktiviteleri ve mikroorganizma sayıları alt topraklara göre yüksek değerler göstermiştir. Kadıŏlu (2007)'nun incelediği toprakların A horizonlarında benzer sonuçlara rastlanmıştır.

Mikroorganizmalar tarafindan üretilen ve toprak ortamında organik madde, killer ve kolloidler tarafından tutulan katalaz enzimi, bitki kökenli hidrojen peroksit $\left(\mathrm{H}_{2} \mathrm{O}_{2}\right)$ bileşiğini su ve oksijene parçalar (Dick 1994). Toprakta mikroorganizma sayıları ile enzim aktiviteleri arasında bir ilişki olmasına rağmen toprakların $\mathrm{C}$ ve $\mathrm{N}$ kapsamları gibi birçok özelliğini birlikte değerlendirmek gerekmektedir. $\mathrm{Bu}$ çalışmada, katalaz enzim aktivitesi mikroorganizma sayıları gibi yüzeyde daha fazla ölçülmüsstür. Benzer sonuçlara uzun süre işlenen ve işlenmeyen topraklarda Sebastian et al (2010)'ın yaptıkları çalışmada rastlanmıştır. Araştırmacılar; derinlik arttıkça katalaz enzim aktivitesinin azaldığını, bu alanlardan katalaz enzimi en yüksek olanların işlenmeyen alanlar olduğunu belirtmişlerdir. Toprakta mikroorganizmaların temel yapı taşları olan karbon ve azot elementlerinin topraktaki değişimleri mikroorganizma sayılarını doğrudan etkileyen en önemli unsurlardandır (Eldor 2007). Bu nedenle karbon ve azot özellikleri biyolojik özelliklere dâhil edilmiştir.
Islah uygulamaları bakımından D ve E alanlarının kontrole göre mikroorganizma sayıları düşük olmasına rağmen, bu uygulamaların karbon ve azot içerikleri yüksek bulunmuştur. Fidan (2002)'ın 1slah konusunda Elaziz mera topraklarında yaptığ çalışmasına göre; korunga bitkisi ekilen, toprak işlemesi ve gübreleme yapılan alanlarda toprakta azot miktarı önemli derecede artmıştır.

Toplam karbon içeriği en fazla D uygulamasında belirlenmiştir. Bunun en önemli nedenlerinden biri olarak bu uygulamanın kuru ot veriminin yüksekliği (Özaslan Parlak et al 2011a) nedeni ile toprağa kök ve saplarla dönen organik madde miktarının fazla olmasıyla ilişkilendirilebilir. Bu tür yapay meralarda ot veriminin yüksek olduğuna dair araştırmalar (Gökkuş et al 2011; Fırıncıoğlu et al 2007; Oğuz 2012; Çetiner 2009) bulunmaktadır.

\subsection{Toprak fiziksel özellikleri}

Toprak fiziksel özelliklerinden agregat stabilitesi, kum-silt-kil yüzdeleri, kuru hacim ağırlığı ve tane yoğunluğu özellikleri 1slah uygulamaları ve derinlik farklarına göre önemli değişimler göstermiş (Çizelge 5); bünye özelliklerinde uygulamalar ve derinlikler arasında istatistikî farklar gözlenmiştir. Bünye üçgenine uygulanan kum, silt ve kil miktarlarına göre A ve E alanları kil (C), diğer alanlar killi tın (C L) bünye sınıfına girmişlerdir.

Toprak fiziksel özellikleri incelendiğinde (Çizelge 5); üst toprakların agregat stabilitesi, kuru hacim ağırlığı ve tane yoğunluklarının yüksek olduğu, kum, silt ve kil yüzdeleri bakımından ise toprak derinliklerinin önemsiz olduğu görülmüştür. Toprak fiziksel özellikleri ıslah uygulama alanlarına göre incelendiğinde, $\mathrm{C}$ tipi ıslah alanının en yüksek dayanıklı agregatlara sahip olduğu görülmüştür. Diğer uygulamalar arası fark önemsiz olmuştur. C tipi ıslah alanında ot öldürücülerle çalı mücadelesi yapıldıktan sonra çalılardan boşalan yerlere mera bitkileri ekimi yapılmıştır. Bu alanda topraklarının gerek kil ve gerekse karbon içerikleri diğer uygulamalardan düşük olmasına rağmen, doğal ot vejetasyonunun korunmuş olması gelişmiş kök sistemlerine neden olabilir. Gelişmiş kökler ise agregat stabilitesini artıran unsurlardandır. 
Çizelge 5- Toprak fiziksel özelliklerinin ıslah tipi ve toprak derinliğine göre değişimi

Table 5-Variation of soil physical characteristics with reclamation process and soil depth

\begin{tabular}{|c|c|c|c|c|c|c|}
\hline $\begin{array}{l}\text { Uygulama tipi/ } \\
\text { Toprak derinliği }{ }^{\alpha}\end{array}$ & $\begin{array}{c}\text { Agregat } \\
\text { stabilitesi } \\
\text { (\%) }\end{array}$ & $\begin{array}{l}\text { Kum } \\
(\%)\end{array}$ & $\begin{array}{l}\text { Silt } \\
(\%)\end{array}$ & $\begin{array}{l}\mathrm{Kil} \\
(\%)\end{array}$ & $\begin{array}{l}\text { Kuru hacim } \\
\text { ağırlı } \breve{g ̆}^{-3} \\
\left(\mathrm{~g} \mathrm{~cm}^{-3}\right)\end{array}$ & $\begin{array}{c}\text { Tane } \\
\text { yoğunluğu } \\
\left(\mathrm{g} \mathrm{cm}^{-3}\right)\end{array}$ \\
\hline $\mathrm{A}^{1}$ & $13.64 b^{\#}$ & $33.17 \mathrm{c}$ & $20.65 \mathrm{c}$ & $46.18 \mathrm{a}$ & $1.19 \mathrm{a}$ & $2.64 \mathrm{~b}$ \\
\hline B & $18.68 \mathrm{~b}$ & $39.20 \mathrm{~b}$ & $22.45 \mathrm{bc}$ & $38.35 \mathrm{~b}$ & $1.23 \mathrm{a}$ & $2.76 \mathrm{~b}$ \\
\hline $\mathrm{C}$ & $36.69 \mathrm{a}$ & $43.49 \mathrm{a}$ & $25.29 \mathrm{ba}$ & $31.22 \mathrm{c}$ & $1.30 \mathrm{a}$ & $2.69 \mathrm{~b}$ \\
\hline $\mathrm{D}$ & $18.79 \mathrm{~b}$ & $32.87 \mathrm{c}$ & $27.92 \mathrm{a}$ & $39.21 \mathrm{~b}$ & $1.22 \mathrm{a}$ & $3.04 \mathrm{a}$ \\
\hline E & $13.10 \mathrm{~b}$ & $27.43 \mathrm{~d}$ & $27.41 \mathrm{a}$ & $45.16 \mathrm{a}$ & $1.18 \mathrm{a}$ & $2.84 \mathrm{a}$ \\
\hline$F$ değeri & $21.96^{* * *}$ & $30.05^{* * *}$ & $7.35^{* * *}$ & $20.81^{* * *}$ & $6.33^{* * *}$ & $3.93^{* *}$ \\
\hline $\mathrm{LSD}_{0.05}$ & 7.57 & 3.17 & 3.24 & 3.69 & 0.17 & 0.22 \\
\hline $\mathrm{I}^{2}$ & $22.14 \mathrm{a}$ & 35.67 & 24.09 & 40.24 & $1.20 \mathrm{~b}$ & $2.87 \mathrm{a}$ \\
\hline II & $18.23 \mathrm{~b}$ & 34.79 & 25.40 & 39.81 & $1.25 \mathrm{a}$ & $2.72 \mathrm{~b}$ \\
\hline $\mathrm{F}$ değeri & $4.55^{*}$ & $0.76^{\text {od }}$ & $1.60^{\text {od }}$ & $0.13^{\text {öd }}$ & $5.31^{*}$ & $4.47^{*}$ \\
\hline $\mathrm{LSD}_{005}$ & 3.63 & - & - & - & 0.04 & 0.14 \\
\hline
\end{tabular}

${ }^{a}$, Uygulamalara göre elde edilen ortalamalar için $n=32$, derinliğe göre elde edilen ortalamalar için $n=80$ 'dir. ${ }^{1} \mathrm{~A}, \mathrm{Kontrol}$; B, 15 y1l önce sslah edilen; C, Ot öldürücü ile çalıları öldürülen; D, Dozerle çalıları sökülen; E, Uzun yıllar tarım yapılmaktayken yeniden sslah edilen mera alanlarını göstermektedir. ${ }^{2}$ I, 0-15 cm derinlikten alınan örnekler; II, 15-30 cm derinlikten alınan örnekleri göstermektedir. \#, Farklı harfler aynı sütundaki farklı grupları simgelemektedir. ${ }^{* * *}, \mathrm{P}<0.001$; **, $\mathrm{P}<0.01 ;{ }^{*}, \mathrm{P}<0.05$ önem derecelerini göstermektedir.

Meralarda vejetasyon farklılıkları, tarım alanlarına göre daha heterojendir (Özaslan Parlak et al 2011b). Vejetasyondaki farklılıklar, toprak agregat stabilitesinin lokasyondan lokasyona farkl1 olmasına neden olmaktadır. Toprak karbonu ve agregat stabiliteleri arasındaki korelasyonlar farkl1 olmuştur. Benzer sonuçlar Kavdır et al (2005) tarafından da belirtilmiştir. Toprak agregat stabilitesi üzerine kil içeriğinin etkisi, toprak organik karbon içeriğine göre de değişmektedir (Kavdır et al 2004). Merkezi İran bölgesinde Nael et al (2004) tarafindan yapılan çalışmaya göre; mera alanlarında kontrollü (korumalı) otlatılan ve otlatılmayan alanlarda toprak kalite kriterlerinden infiltrasyon hızı, agregat stabilitesi, toplam $\mathrm{N}$, toplam $\mathrm{C}$ ve mikrobiyal solunum özelliklerini incelemişler ve korumasız meralarda bu özelliklerden agregat stabilitesinin olumsuz etkilendiğini diğer özelliklerdeki değişimlerin önemsiz olduğunu belirtmişlerdir.

İncelenen mera alanlarında kuru hacim ağırlığı ve tane yoğunlukları uygulamalara göre değişmemiş, ancak bu özelliklerin toprak derinliğine göre değişimi önemli olmuştur. Üst topraklarda her iki özellik de yüksek seviyelerde bulunmuştur. Çetiner (2009), aynı bölgede yapay mera alanında incelediği toprak özelliklerinden hacim ağırlı̆ğ, organik madde, toplam azot ve alınabilir potasyumun arttığını belirtmiştir. Tane yoğunluğu dozerle çalıları sökülen alanda (D) en yüksek, ot öldürücü kullanılan alanda (C) ise en düşük değerlerde olmuştur. Rusya mera alanlarında yapılan bir araştırmada, toprakların hacim ağırlığının yılaşırı otlatmaya göre her yıl otlatılan meralarda arttığı belirtilmiştir (Mikhailova et al 2000). Benzer şekilde Öztaş et al (2003) yaptıkları çalışmada, Erzurum şartlarında sürekli aşırı otlatılan bazı meralarda, bitki deseninin değiştiğini ve mera topraklarının erozyon katsayısının kısmen arttığını belirtmişlerdir.

Toprak kalitesi hakkında fikir veren bir başka araştırmada, araştırmacılar Erzurum ili tarla koşullarında 30-60 cm toprak derinliklerinde toprak penetrasyon direncini ölçerek bazı toprak özellikleri ile ilişkisini sorgulamışlardır. Araştırmacılar; 
toprakların penetrasyon direncinin düşük olduğu alanlarda kütle yoğunluğunun da düşük değerler aldığını, toprakların agregat stabilitesi, nem içerikleri ve organik madde içeriklerinin ise yüksek değerler aldığını belirtmişlerdir (Turgut \& Öztaş 2012).

\section{Sonuçlar}

Farklı uygulama yapılarak 1slah edilen Hacıpehlivanlıköyümerasında sslahuygulamalarının etkisi incelenen tüm toprak özellikleri bakımından önemli seviyelerde olmuştur. Derinlik etkisi bakımından, incelenen özelliklerden kireç yüzdesi ve bünye öğeleri dişında tüm özelliklerin değiştiği görülmüştür. Uygulama ve derinliğin birlikte etkisi (interaksiyonu) önemsiz bulunmuştur.

Türkiye'de meraların ıslahına devam edileceği son zamanlarda çıkarılan kanun ve yönetmeliklerden anlaşılmaktadır. Mera sslahında yalnızca ot verimi merkezli düşüncelerden kaçınılması, bu kapsamda toprağa yapılan müdahelelerin sonuçları konusunda çok dikkatli davranılması gerekmektedir. Türkiye topraklarının \% 80'den fazlası erozyona hassas durumdadır (Dizdar 2003). Türkiye meraları da bu kapsamda değerlendirilerek mera topraklarının kalite kriterleri konusunda çok sayıda çalışma yapılması gerekmektedir. $\mathrm{Bu}$ çalışmaların meraya müdahele etmeden önce yapılması durumunda daha önemli bilgiler elde edilebilir. Toprak kalite özelliklerinin ıslah uygulamaları sonrası değişiminin incelendiği bu tür çalışmalar yanında, öngörü çalışmaları ve uzun yıllardaki değişimlerin de izlemesine yönelik çalışmaların yapılması gerekmektedir. Kırılgan bir ekosistem aracı olan mera alanlarındaki toprakların kalitesini, mera 1slah yöntemlerinin etkileyebileceği unutulmamalıdır. Toprak sınırlı bir kaynaktır, korunmalı ve sürdürülebilirliğini sağlayacak her türlü çalışma desteklenmelidir.

\section{Teşekkür}

Çanakkale Onsekiz Mart Üniversitesi Bilimsel Araştırma Komisyonu'na ekonomik desteklerinden dolayı teşekkür ederiz (Proje No: 2007/88). Ayrıca düzeltmelerinden dolayı Sayın Dr. Yakup ÇIKILI ve Dr. Mevlüt AKÇURA'ya teşekkür ederiz.

\section{Kaynaklar}

Allison L E \& Moodie C D (1965). Carbonate. In: C A Black (Eds), Methods of soil analysis, Part 2: Chemical and microbiological properties, Madison, Wisconsin, USA, pp. 1379-1396

Beck T H (1971). Die Messung Katalasen Aktivitaet Boden Z. Pflanzenernaehai Sodek 130: 68-81

Blake G R \& Hartge K H (1986). Bulk density. In: A Klute (Eds), Methods of soil analysis. Part 1. $2^{\text {nd }}$ edition, Agron. Monogr. 9, ASA and SSSA, Madison WI, USA, pp. 363-376

Bouyoucos G J (1951). A recalibration of hydrometer for making mechanical analysis of soils. Agronomy Journal 43 (9): 435-438

Çetiner M (2009). Yapay bir merada otlatmanın bitki örtüsü ve toprak özelliklerine etkisi. Yüksek lisans tezi, Çanakkale Onsekiz Mart Üniversitesi Fen Bilimleri Enstitüsü (Basılmamış), Çanakkale

ÇOB (2007). http://www.bcs.gov.tr/documents/ UBSEP-2007.pdf, Ulusal Biyolojik Çeşitlilik Stratejik Eylem Planı, T.C. Çevre ve Orman Bakanlığı (Erişim Tarihi 27.07.2013)

Dick R P (1994). Soil Enzyme Activity as an Indicator of Soil Quality. In: J W Doran et al (Eds), Defining soil quality for a sustainable environment, Madison WI, USA, pp. 107-125

Dizdar M Y (2003). Türkiye'nin Toprak Kaynakları. TMMOB Mühendisleri Odas1, Teknik Yayınlar Dizisi No:2, Ankara.

Eldor A P (2007). Soil Microbiology, Ecology and Biochemistry. Academic Press, USA

Fırıncioğlu H K, Seefeldt S S \& Sahin B (2007). The effects of long-term grazing exclosures on range plants in the Central Anatolian Region of Turkey. Environmental Management 39 (3): 326-337

Fidan C (2002). Doğu Anadolu (Elaziz) mera topraklarının 1slahı üzerine araştırmalar. Doktora tezi, İstanbul Üniverstesi Fen Bilimleri Enstitüsü (Basılmamış), İstanbul.

Gökkuş A, Alatürk F \& Özaslan Parlak A (2011). Çanakkale'de otlatma alanlarının hayvancılıktaki önemi. Çanakkale Tarımı Sempozyumu (Dünü, Bugünü ve Geleceği): 10-11 Ocak, Çanakkale, s. 71-79 
Gökkuş A, Baytekin H, Hakyemez B H \& Özer İ (2001). Çanakkale'nin sürülüp terk edilen çalılı meralarında yeniden bitki gelişimi. Türkiye 4. Tarla Bitkileri Kongresi. Cilt: III, Çayır Mera Yem Bitkileri: 17-21 Eylül, Tekirdağ, s. 13-18

Heady H (1973). Structure and function of climax. Arid Shrublands, Proc. of Third Workshop of the United States/Australia Rangelands Panel, March 26-April 5, Tuscon, Arizona, 73-80

Hoffmann E \& Teicher K (1961). Ein kolorimetrisches Verfahren zur Bestimmung der Ureaseaktivit/at in: B6den. Z Pflanzenernaehr Dtingung Bodenkd 95: $55-63$

Hofmann E \& Hofmann G (1966). Determination of soil biological activity with enzymatic methods. Advanced Enzymology 28: 365-390

Holechek J L, Pieper R D \& Herbel C H (2004). Range Management: Principles and Practices, $5^{\text {th }}$ edition. Pearson Education Inc, Upper Saddle River, New Jersey

Jackson M L (1958). Soil Chemical Analysis. PrenticeHall Inc, Englewood Cliffs New Jersey, USA

Kadığlu B (2007). Bazı toprak kalite indeks parametrelerinin işlemeli tarım ve mera alanlarında farklı topoğrafik pozisyonlara bağlı olarak değişimi. Yüksek lisans tezi, Atatürk Üniversitesi Fen Bilimleri Enstitüsü (Basılmamış), Erzurum

Kavdır Y, Ekinci H, Yüksel O \& Mermut A (2005). ${ }^{13} \mathrm{C}$ CP/MAS-NMR spectra of soil organic matter and stability of soil aggregates affected by forest wildfires in Canakkale, Turkey. Geoderma 129: 219-229

Kavdır Y, Özcan H, Ekinci H, Yigini Y \& Yüksel O (2004). The influence of clay content, organic carbon and land use types on soil aggregate stability and tensile strength. Turkish Journal of Agriculture and Forestry, 28 (3): 155-162

Kemper W D \& Rosenau R C (1986). Aggregate Stability and Size Distribution. In: A Klute (Eds), Methods of Soil Analysis, Part 1. Physical and mineralogical methods. Madison WI, USA, pp: 425-442

Kirsten W J (1983). Organic Elemental Analysis. Academic Press, New York, USA

Kökten K (2005). Çukurova bölgesinde maki tipi vejetasyonun değişik mera 1slahı yöntemleriyle geliştirilme olanakları. Doktora tezi, Çukurova Üniversitesi Fen Bilimleri Enstitüsü (Basılmamış), Adana
Lal R (2011). Sequestering carbon in soils of agroecosystems. Food Policy 36: 33-39

Langdale G W, West L T, Bruce R R, Miller W P \& Thomas A W (1992). Restoration of eroded soil with conservation tillage. Soil Technology 5: 81-90

Lavorel S, Rochette C \& Lebreton J D (1999). Functional groups for response to disturbance in Mediterranean old fields. Oikos 84: 480-498

Liu Y, Horisawa S \& Mukohata Y (2010). Effect of seed coating on plant growth and soil conditions: A preliminary study for restoration of degraded rangeland in the inghai-Tibetan Plateau. Grassland Science 56: 145-152

Lund H G (2007). Accounting for the World's Rangelands. Rangelands 29 (1): 3-10

MGM (2013). Meteoroloji Genel Müdürlüğü. http:// www.mgm.gov.tr/ veridegerlendirme/ (Erişim Tarihi 26.07.2013)

Mikhailova E A, Bryant R B, Cherney D J R, Post C J \& Vassenev I I (2000). Botanical composition, soil and forage quality under different management regimes in Russian grasslands. Agriculture, Ecosystems and Environment 80: 213-226

Montalvo J, Casado M A, Levassor C \& Pineda F D (1993). Species-diversity patterns in mediterranean grasslands. Journal of Vegetation Science 4: 213-222

Mülayim M (1980). Tabii merada herbisitlerle hazırlanan tohum yatağında suni mera kurma olanakları üzerinde araştırmalar. Doktora tezi, Ankara Üniversitesi Fen Bilimleri Enstitüsü (Basılmamış), Ankara

Nael M, Khademi H \& Hajabbasi M A (2004) Response of soil quality indicators and their spatial variability to land degradation in central Iran. Applied Soil Ecology 27: 221-232

Nannipieri P (1994). The potential use of soil enzymes as indicators of productivity, sustainability and pollution. In: C E Pankhurst, B M Double, V V S R Gupta \& P R Grace (Eds), Soil Biota Management in Sustainable Farming Systems, CSIRO East Melbourne, pp. 238244

Nortcliff S (2002). Standardisation of soil quality attributes. Agriculture, Ecosystems \& Environment $\mathbf{8 8}$ (2): 161-168

Oğuz İ (2012). The Effect Of Planting, Protection And Fertilization Applications On Vegetation, Soil Properties, Soil Loss And Soil Water Content in Central 
Anatolia Degraded Rangeland. Carpathian Journal Of Earth And Environmental Sciences 7 (3): 167-173

Ojima D S, Dirks B O M, Glenn E P, Owensby C E \& Scurlock J O (1993). Assessment of C budget for grasslands and drylands of the world. Water Air Soil Pollution 70: 95-109

Olsen S, Cole C, Watanabe F \& Dean L (1954). Estimation of available phosphorus in soils by extraction with sodium bicarbonate. USDA Circular Nr: 939, US Gov. Print. Office, Washington DC,USA

Özaslan Parlak A (2011). Çanakkale yöresinde çalılı meraların önemi. Çanakkale Tarımı Sempozyumu (Dünü, Bugünü ve Geleceği): 10-12 Ocak, Çanakkale, s. 489-496

Özaslan Parlak A, Gökkuş A \& Hakyemez B H (2011a). Değişik yöntemlerle 1slah edilen meranın bitki örtüsündeki değişim (yayınlanmamış). ÇOMÜ, 2007/89 no'lu proje raporu

Özaslan Parlak A, Gökkuş A, Hakyemez B H \& Baytekin $\mathrm{H}$ (2011b). Forage yield and quality of kermes oak and herbaceous species throughout a year in Mediterranean zone of western Turkey. The Journal of Animal \& Plant Sciences 21 (3): 513-518

Öztaş T, Koc A \& Comaklı B (2003). Changes in vegetation and soil properties along a slope on overgrazed and eroded rangelands. Journal of Arid Environments 55: 93-100

RG (1998). http://www.kentli.org/yasa/4342.htm, 4342 Sayılı Mera Kanunu, Resmi Gazete 28.02.199823272 (Erişim Tarihi: 27.07.2013)

Richards L A (1954). Diagnosis and Improvement of Saline and Alkali Soils. USDA Agriculture Handbook 60, Washington DC, USA

SAS (2000). SAS. STAT User's guide. $9^{\text {th }}$ version, SAS Inst. Inc. Cary, $\mathrm{NC}$

Sebastian U, Sabine T, Hofmann B \& Christen O (2010). Biological soil properties in a long-term tillage trial in
Germany. Journal of Plant Nutrition and Soil Science 173 (4): 483-489

Seligman N G (1996). Management of Mediterranean grasslands. In: J Hodgson \& A W Illius (Eds), The Ecology and Management Og Grazing Systems, CAB International, Wallingford, UK, pp. 359-392

Sternberg M, Gutman M, Perevolotsky A, Ungar E D \& Kigel J (2000). Vegetation response to grazing management in a Mediterranean herbaceous community: A functional group approach. Journal of Applied Ecology 37: 224-237

Stoddart L A, Smith A D \& Box T W (1975). Range Management (3rd ed.). McGraw-Hill Book Co., New York, USA

Şekercioğlu C H, Anderson S, Akçay E, Bilgin R, Can O E, Semiz G, Tavşanoğlu C, Yokeş M B, Soyumert A, İpekdal K, Sağlam İ K, Yücel M \& Dalfes H N (2011). Turkey's globally important biodiversity in crisis. Biological Conservation 144 (12): 2752-2769

Turgut B \& Öztaş T (2012). Toprak penetrasyon direncine etki eden toprak özelliklerinin yersel değişim paternlerinin jeoistatistiksel yöntemlerle belirlenmesi. Tarım Bilimleri Dergisi-Journal of Agriculture Sciences 18 (2): 115-125

Winogradsky S N (1952). Soil Microbiology. Problems and Methods. USSR Academy of Sciences, Moscow (in Russian).

Wollum A G (1982). Cultural Methods for Soil Microorganisms. In: A L Page et al (Eds), Methods of soil analysis, $2^{\text {nd }}$ edition, Part 2, Chemical and Microbiological Properties, SSSA Book Series (9), Madison WI, USA, pp. 781-802

Zavala L M, Granged A J P, Jordán A \& Bárcenas-Moreno G (2011). Post-fire evolution of soil properties and vegetation cover in a Mediterranean heathland after experimental burning: A 3-year study. Geoderma 164: 85-94 